\title{
Garudeya Batik \\ The Relief Sculpture "Garudeya" of Sukuh Temple as an Idea of Batik Creation
}

\author{
Dharsono \\ Departement of Fine Art, Faculty of Fine Art and Design, Indonesian Institute of the Arts, \\ Surakarta, Indonesia
}

\begin{abstract}
Creative artistic batik inspired by Garudeya sculptures carved on the reliefs of Sukuh Temple in Karanganyar, Central Java, Indonesia. The process of making batik is focused on preserving traditional arts as a form of cultural resilience. Preservation can be interpreted as maintaining, caring for and protecting. Conservation is the preservation of the form of development and use of values. Conservation is more prioritizing in the development of response alternatively to the condition of art and culture globally. This study aims to make prototypes and designs of batik as artistic creations sourced from reliefs of Garudeya sculptures carved on the outer walls of Sukuh Temple. To achieve this goal, it requires an experimental method of reproductive form with garap (work on) innovation, a sanggit work with a concept of revitalization. The method of creating sanggit works has a level of importance that refers to the form of traditional arts preservation, by trying to provide alternative artworks with the reproduction technique of garap innovation. Technically experienced processing reduction through the elements; contour lines, colouring techniques and content fields in thematic engineering. Conservation with the concept of revitalization and reinterpretation, producing prototypes and batik designs as artistic creations inspired by the Garudeya sculpture carved into the reliefs of Sukuh Temple. The artistic creation of the "Garudeya" batik inspired by the Garudeya Sculpture is a symbol of Garuda as a liberator figure who is part of the search for Tirta Amerta (living water) story contained in The Adiparwa book. The creative design of batik as an innovative design with the concept of batik patterns which layouts: (1) The main motive was inspired by the aspirations of the Garudeya sculpture carved in the reliefs of the Sukuh Temple, (2) Interlude motives (supporting motives) are made oriented to mountain flora around the mountains where Sukuh Temple is located.
\end{abstract}

Keywords: Artistic Creation, Conservation, Prototype, Garudeya

DOI: 10.7176/ADS/79-04

Publication date: December $31^{\text {st }} 2019$

\section{Introduction}

Artistic creative entitled "Garudeya Batik" is a typical batik of Karanganyar Central Java Indonesia, which was created with aspirations for the Garudeya sculpture carved in the relief of Sukuh Temple in Karanganyar Central Java Indonesia. Batik creation is focused on preserving traditional arts as a form of cultural resilience. Preservation can be interpreted as maintaining, caring for and protecting. Conservation is the preservation of the development form and use of values. Conservation is more prioritizing in the development of response alternatively to the condition of art and culture globally.

To welcome the global era, the alternative that we have to build is how to conduct local studies (traditional art) that can become an alternative to the development of art towards a global ideology, so that global phenomena will become increasingly local. The development of modern art with a touch of the traditional art of the Nusantara (Archipelago), which we later refer to as a sanggit work of art in the Indonesian paradigm of fine artworks. Sanggit artwork is a strategy to build the future of Indonesian fine arts with the character and identity of Indonesian roots in Indonesia.

Sukuh Temple is located at the foot of Mount Lawu, Ngargoyoso District, Karanganyar Regency is an area with natural potential and very interesting historical heritage developed as the identity of Karanganyar Regency. Beautiful natural scenery, the expanse of Mount Lawu, hills, tea and onion plantations in the Ngargoyoso region from year to year increasingly crowded by tourists both local (domestic) and foreign (international). 


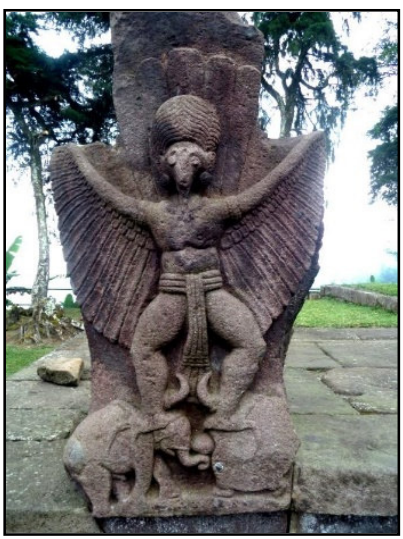

Image: Garudeya Sculpture of Sukuh Temple (photo: Arthea 2017)

The Garudeya sculpture is a symbol of Garuda as a liberator figure who is part of the search for Tirta Amerta (water of life) story contained in The Adiparwa book, the first book of The Mahabharata. On the tail of the Garuda there is an inscription (inlay writing) that reads, lawase rajeg wesi duk pinerp kapeteg dene wong medang ki hempu rama karubuh alabuh geni harbut bumi kacaritane babajang mara mari setra hanang tang bango (iron stabs in a pinerp cap and a man goes out of his head as a fireplace ravages the earth's crust when it comes to attacking a crane) according to Darmosoetopo (1984). In essence, this inscription is a sign of a suryasengkala which is symbolic of the year 1363 Saka (1441 AD).

Then as part of the story of the search for Tirta Amerta in this section, three tortoises statues symbolize the earth and the incarnation of Lord Vishnu. The shape of these tortoises resemble table and there is a possibility it was designed as a place to put offerings. A pyramid whose top is truncated symbolizes Mount Mandaragiri whose top is taken to stir up the ocean in search of Tirta Amerta.

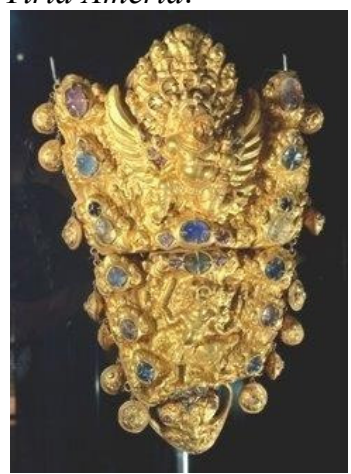

Image: Goruda Artifact (Garudeya), a gold artefact that was discovered by the Seger brothers in 1989, now stored in the Empu Tantular Museum. By the general public, the object is known as the 'Garudeya' ornament. Based on observations, some identities were obtained that there were sculptured on both wrists and left palms in which there was a flame decoration, sculptured an eagle carrying Amerta jars, wearing cloth under the jlamprang motif, giant sculptured carrying mace, wearing cloth under the jlamprang motif, sculptured of human figures that demonic dancing, sculptured of a forest landscape with some people dressed in hermits, and circir decorations on both sides. The object is an artefact from the Hindu-Buddhist era, which is an ideology fact related to belief or religion. The decoration is loaded with tantric philosophy. Therefore the object is known as 'Yantra', which is as an aid in a ceremony. These objects have many similarities with the arts that developed during the Singasari period. So historically these objects can be associated with king Kertanagara, as a king who was diligent in carrying out tantric ceremonies. The sculptures s in the unity of the object are thought to be a sengkala which can be read as a number in 1212 saka or $1290 \mathrm{M}^{1}$.

Based on observations of artefacts in the gold collection room of the Empu Tantular Museum, as well as the visuals that were obtained, it is very appropriate to make careful observations of parts by part of the object, which is as follows :

The upper part forms curly curves, which is decorated with tendrils that are recalcitrated from lotus flora, the edges of which form flames. While in the tendrils there is a sculpture of the left wrist with the palm whose fingers are open, out of the red lotus petals are five sheets in bloom. On the inside of the left palm, there is a stroke-like the letter ' $\mathrm{S}$ ', as if a tongue of fire came out of its veil. This curly curved section is like a tall hood that forms a

\footnotetext{
${ }^{1}$ Suwardono (2016)," Revealing the Mystery of Garudeya Gold Jewelry Collection of the Empu Tantular Museum", Seminar, In the Von Vaber building, Empu Tantular Museum, Sidoarjo, East Java. Wednesday, May 18, 2016.
} 
sirascakra to the head of the eagle underneath. In this section, there are 7 places where the gemstones are lost. Underneath is a Garuda bird ornament with the left hand carrying amerta jar, while the right hand is directed to the right with the palm being 'kartarimudra', which is the index and middle fingers forming like scissors, while the other three fingers are joined together by bending under it. Garuda faces facing towards the front with an open beak. Curly-haired, rounded eyes. Wearing kundala (earrings), hara (necklace), keyura (shoulder protector), kankana (bracelet), kuchabandha (belt/chest decoration), and upavita (caste rope). Wearing a fabric under the motif of 'jlamprang', the decoration of four lotus petals. The position of the two legs is like an eagle relief found in the Kidal Temple and the statue of Hemisphere, except that the left leg of halve and Garuda in the Kidal Temple, the calf and soles of the feet are bent and hidden in the left thigh. While this eagle and calf and the sole of his left foot was thrown out towards the left, so it looked like running. Both wings are spread wide like in the Garuda Kidal Temple, while the Hemisphere Garuda's wings seem partially closed (this is certainly influenced by the factor of the stone material which makes it impossible to carve a fully expanded Garuda wing).

The eagle sculpture image behind him is full of ornamentation of vine and flora so that it depicts the view of the forest, which on either side of the eagle figure, the lower and upper sides, there are carved of human figures each in a niche. The human figure on the upper right side sits with both hands resting on the knees of the legs bent upwards (like someone sitting in front of a fireplace). Bottom right, a someone sits with his left leg bent up, his right leg crossed, his left hand stroking his protruding belly, while his right hand dangles resting, in front of him there is a bowl. At the top left, there is the same figure as the bottom right picture. While the lower-left one sits meditatively with the 'padmasana' attitude with the 'dhyanamudra' hand gesture, which is both palms are held together in the laps of both feet with palms facing up (reminiscent of the Amitabha Buddha statue).

Behind his head is the 'sirascakra', which is the circle of purity. In this section, there are 21 places where gemstones still exist.

The second area (the middle part) is a picture of a giant figure standing as if 'pratyalidha', which is the right leg is bent and the left leg is straight. it has dreadlock hair with a headband like a crown with a 'two horns' pattern (this horn resembles the head horn of Kala in East Javanese temples, especially the head of Kala in Jago Temple), which in the centre there is a flower decoration. The left hand is swung to the left side with the 'abhayamudra' palm gesture, while the right hand is directed to the upper right side carrying a mace weapon. The giant face faces forward with rounded bulging eyes and a grinning mouth with teeth and fangs. It wearing kundala (earrings), hara (necklace), keyura (shoulder protector), kankana (bracelet), kuchabandha (belt / chest decoration), and upavita (caste rope). Also wearing a cloth under the 'jlamprang' motif filled with four lotus petals, only this one is more complicated than the filling of the jlamprang fabric garuda motif.

Similar to the Garuda picture, the background of this giant picture is also full of flora decoration with shady trees depicting forest views, on either side of the giant figures on the upper side there are figures of dressing as hermit men. The human figure on the upper right sits cross-legged in the niche, with the right hand placed straight down, resting, the left hand placed in the lap of the left thigh. Above right, someone standing is looking at the person who sat with his right hand raised shoulder level, while his left hand dangling down. Far behind him was a wooden hall building. In this section, there are 12 places where the gemstones are still there.

The third field is below. Pictured of someone standing in a dancing position. Both hands raised, with both palms looking up. While both legs bent with tiptoe. This figure has a giant face with bulging eyes and a grinning mouth. Crown by his hair which is a high bun (jata-makuta). There is a 'sirascakra' (circle of purity) behind the head. Wearing kundala (earrings), hara (necklace), keyura (shoulder protector), kankana (bracelet), kuchabandha (belt / chest decoration), and nupura (binggel). In this section, there are 5 places where the gemstones are still there.

Objects laden with relief and ornamentation sequences are still adorned with circirs (twisted) on the right and left sides, which now 13 left.

\section{Purpose}

The creative design of batik as an innovative design with the concept of batik patterns with layout; (1) The main motive was inspired by the aspirations of the Garudeya statue carved into the reliefs of Sukuh Temple (2) Interlude motives (supporting motifs) are made oriented to the flora of Mount Lawu around Sukuh Temple.

\section{Method}

\section{Steps of Research into Creation}

Following the form of creative research and the type of data source used for the work being designed, steps or methods of creation research are needed.

\section{Utilization of Data Sources}

SourcesResearch Using ethical data sources that is the source of data collected from the study of literature, conducted with a literature review; scientific books, scientific dictates, scientific articles, and scientific papers. (not popular news or articles). Scientific books are scientific books which have been published nationally and have 
ISBNs. The Scientific Dictation is a scientific book that has not been published nationally and does not yet have an ISBN. Scientific Articles are scientific papers that have been published in scientific journals or scientific ejournals and have ISSN. Scientific papers are scientific papers that are presented at seminars or scientific discussions.

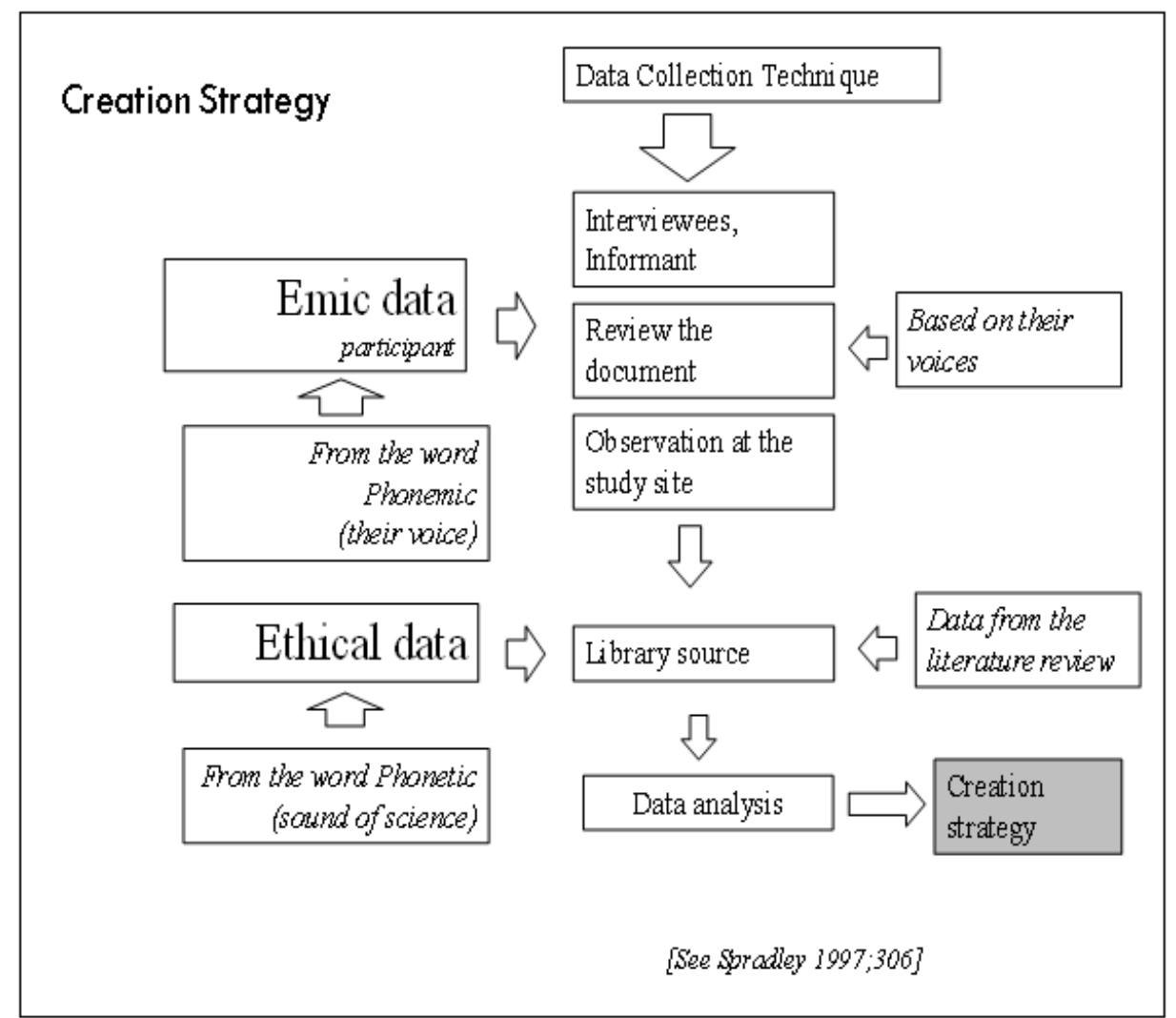

Utilization of emic data sources, carried out by observation, is carried out to observe the subject and object of creation research according to the scope and targets to the aspirations of the artwork to be created or compiled. This data collection technique is supported by documentation tools: photographs of data, or illustration sketches.

Utilization of emic data sources is done by searching document data. This technique is done to get information through document data (archives). Document data is obtained by collecting data sourced from official and unofficial documents (archives) in various regions and/or places, especially regions and/or places related to the research topic. It's important to make a review of the work. For example where or who is the document stored, in which / who collection, in which gallery, etc.

Utilization of emic data sources, conducted by searching interview data is important for the study of special techniques in garap the artwork so that interviews are needed with special sources, to get information about the medium, tools, and garap techniques done by artists in the artwork. The questions raised are focused so that the information collected is detailed according to needs. Selected resource persons use proportional sampling, which is proportional resource persons in their fields, for example, to get good clay and according to what we need we look for sources who are experienced enough about clay, or for example to get information for good screen printing techniques need interviews with experts in their fields, so the information obtained is in accordance with the design of the work.

\section{Artistic Creation Process}

Utilization of emic and ethical data is data used by artists in artistic creative processes, including experimentation, contemplation, and formation (art structure). Experimentation is an activity step carried out by artists and/or designers in carrying out the artistic creation process steps (creation) which includes: (1) try a number of alternative materials that are appropriate and match the creative expression of the art that you are designing, (2) try some alternative individual techniques that match the expressions in the copyrighted art that you have designed, (3) try a number of alternative tools that match the expressions in the copyrighted art that you designed, and (4) Selection of visual concepts (layout). Experiments will produce quality in the selection of materials, techniques, tools, and concepts of the structure that will be used by artists in visualizing the design of their work. Academic artists have the possibility of discovering the concept of experiments carried out, therefore creative experiments in collaboration with laboratories will produce a variety of alternatives needed by artists. Artists choose the right one 
and can help artists express or reveal their feelings individually. Contemplation is the artist's inner wandering in looking for symbols (metaphors). Contemplation is done to search for and find symbols (metaphorical language) that will become icons in the artistic creative process in the creation of art. In reflection, artists and/or designers will find symbols and/or metaphors. The symbol will be used as the expression language, and then it will be used as the main (major) motif, supporting motif and fill motif. The main motive (major), will be the centre of interest and which will be the idiom of communication that is spread through the media and becomes a personal expression. The main motive is a metaphorical idiom that provides philosophical information that is very individual. But the metaphorical idiom will invite interpretation and multiple interpretations in the living process. There are times when metaphorical idioms are not the result of contemplation but are the result of natural interpretations that have undergone a process of imagination, sometimes metaphorical idioms are symbols or motives borrowed from traditional idioms or artefacts chosen as symbols of reading or symbols of expression. But there are times when the metaphorical idiom is a sign language that has become the agreement of the community. The metaphorical presentation in art is an idiom that exists as a communication between the artist and the audience, even though it is very personal, and invites interpretation. Metaphors (symbols) as personal expressions will be bound by the values and principles of the structure and the formation of works of art creation and/or design of design works in the aesthetics of the forms presented.

The formation is a draft arrangement or composition designed to obtain the form or structure of the work. Structure is a composition that will always be related to (1) the quality of the elements as designed art icons, (2) the principle of the layout structure (harmony, contrast, rhythm (repetition), gradation), which is designed, (3) the principle of the structure includes the balance (formal/informal balance) and unity) designed to achieve a unity. The arrangement will produce dynamics (soft, medium, and strong), and these dynamics will produce a certain atmosphere and/or certain impressions.

\section{Literature Review}

The literature used in this study includes literature and scientific articles on the study of aesthetic culture, fine arts, and batik.

Geertz, C. (1981), Abangan, Santri, Priyayi dalam Masyarakat Jawa (Abangan, Santri, Priyayi in Javanese Society; translated by Aswab Mahasin Original book Title The Religion of Java), Jakarta, Dunia Pustaka Jaya, 232 Clifford Geertz (1981: 232) says: Since the craft of folk batik entering the palace on the island of Java, then the aristocratic stamp began colouring Javanese classical batik. Although it did not change the original style (especially on the symbol of the ornament), as a form of decoration, the delicate touch of the hands of the royal nobility succeeded in identifying the work as a product of the palace. What is said "Aristocratic Batik", is fine hand-drawing batik art (batik Tulis/ canting) that reflects the idealization of upper-class Javanese culture (nobility). Geertz said it was a culture of "refinement". The statement is a note that there has been legitimacy from the people's batik (through the Wicitran family company) succeeded in elevating the degree of being a batik company in the palace environment, and getting a stamp as aristocratic batik (Babaran hand-drawing batik of the palace).

Djoko Adi Prasetyo titled "Cerminan Etika dalam Hubungan Antar Manusia, Analisis pada Beberapa Ornamen Candi Sukuh" ("Reflections on Ethics in Human Relations, Analysis of Some Sukuh Temple Ornaments") in the Journal of Media Masyarakat Kebudayaan dan Politik (Media Culture and Politics) volume 19 number 3 of 2006 explains the ethical relations and visualization of artefacts in Sukuh Temple. This article is useful as a basis for ethical considerations in the selection of Sukuh Temple as one of the artefacts raised in the visualization of batik motifs in this study.

Wuryantoro, E. (1986), Wuryantoro, E. (1986), “Wdiham dalam Masyarakat Jawa Kuna abad IX-X (sebuah telaah Data Prasasti)" Makalah Pertemuan Ilmiah Arkeologi, Cipanas ("Wdiham in Ancient Javanese Society of the IX-X Century (a Study of Inscription Data)" Papers of the Archaeological Scientific Meeting Paper, Cipanas). In the paper explained that the dynamics of classical Javanese batik was initially closely related to the copyright symbol of the status of the palace in Java. The writings contained in the rocks of the IX and X centuries provide information on the existence of a complicated inventory of patterns and types of textiles suitable for use by kings or officials of the higher, middle and lower classes (Edhi Wuryantoro 1986: 1-15).

Soedarmono. (1990), Dinamika kultural batik klasik Jawa ( Kajian seni batik klasik), Makalah saresehan budaya, Surakarta: TBS, (Cultural dynamics of Javanese classical batik (Study of classical batik art), Cultural essay papers, Surakarta: TBS), states that around 1769 Susuhunan (called the ruling prince) Surakarta Hadiningrat, issued a formal decision (Java: Pranatan) that "Jilamprang" motifs/patterns are prohibited from being used by anyone except Susuhunan himself and his sons and daughters. In 1785, the Sultan of Yogyakarta proclaimed a parang rusak pattern for his personal needs. Then in 1792 and 1798 through Pengageng (officials) the palace issued further restrictions on the patterns used for certain purposes in the palace environment, which is designating several patterns such as sawat lar, parang rusak, cumengkirang and udan liris. In line with the pranatan, a group of batik craftsmen from the Wicitran family company entered the Surakarta Hadiningrat palace, then was awarded the title of nobility in the palace environment. (1990: 2). 
Kertcher, W (1954), Kertcher, W (1954), Perisdutrian Batik di Pulau Jawa, Badsche Analin \& Suga Fabric (Perisdutrian Batik in Java, Badsche Analin \& Suga Fabric), illustrates the increasing competition both in quality and quantity, from private companies in Laweyan, Chinese companies in the Kampung Sewu area and Margoyudan Surakarta were underestimated from the start, resulting in the destruction of the company. Such conditions are following the report P. de. kat Angelino, around 1930 in Surakarta there were 236 indigenous batik entrepreneurs, 88 Arabs, 60 Chinese and 3 Europeans (Kertcher, 1930: 321). These data provide information that batik developed and experienced glory after the development of products outside the palace. Regional batik products are progressing because they are oriented towards the community's economy; Kedung Gudel Sukaharjo Batik, Polokarto Mojolaban Batik, and Matesih Karanganyar Batik. But the King and palace are still a source of strength to provide cultural motivation. In this case the existence of kings and palaces as a cultural force which is a source of inspiration and provides a coveted belief by the community. The use of batik as clothing is considered to have a status value. The public's view of the palace as a cultural centre is very attached giving one proof that batik is an item that is still favoured by the Javanese people.

Thomas Kitley (1987), argues that batik is popular and used, and even able to survive as everyday clothing, both as formal clothing or for semi-official. That is why batik has a status in Javanese society. Changes in dynamics and changes in social institutions have an impact on cultural behaviour, especially human needs. The fall of palace batik dissolved the palace pranatan, as a result, all types of batik worn by the community. But the community's view of the palace as a cultural centre is very attached, even the King and the kingdom are still considered as a source of strength to provide a cultural motivation. The further development of batik in daily life still provides an understanding of batik as a symbol of the status of the palace, which is desired by the community. Batik is used as clothing that is considered to have status values.

The subsequent batik development underwent a dynamic development, not only used by men and women as "jarik" (batik fabric) but developed and used as long-sleeved batik, as official and daily clothing. The interrelationship between society, culture, cultural behaviour and social institutions in society cannot be separated and influence each other. The dynamics of the development of batik diverted the attention of batik consumers. People turn to batik motif cloth textiles, while the Indonesian bourgeoisie uses batik alus cloth for the purposes of official events and official parties. The dynamics bring batik (batik canting) to its exclusive throne. Nowadays, written batik has a clear position in its essence (Prisma, 5 May 1987: 56-57). This framework gives the meaning of classical batik as a symbol of Javanese cultural expression, is a cultural endurance in the form of preservation and development, in accordance with human and community needs, environmental resources, and social institutions that exist in Javanese society.

Sewan Susanto (1980), Seni Kerajinan Batik Indonesia (Indonesian Batik Handicraft). Motives and patterns in classical batik are arranged based on the repetition of "batik patterns". Batik patterns consist of a combination of motifs arranged by the type of batik following provisions that are considered standard (Java: pakem (standard)). The layout of batik is a blend of patterns consisting of the main motif, filler motif (interlude), and the filling motif. The classical batik colour arrangement, in general, shows that dark blue (wulung), dark brown (dragemsogan) and white are more preferred by people as the background of the ornaments. In some cases these colors are easily obtained from natural plant materials. Such as batik kelengan (black and white) is made with the basic colour of wulung, wedelan or with a black colour that is easily obtained. Dark blue is obtained from indigo plants and black from ketepeng leaves (Sewan Susanto 1980: 9).

Bagus Indrayana (2015) "Pengembangan Motif Batik Berdasarkan Ragam Bentuk Mainan Tradisional Jawa dan Aplikasinya dalam Industri Fesyen" ("Development of Batik Motifs Based on the Variety of Traditional Javanese Toy Forms and Their Applications in the Fashion Industry"). The research resulted in batik motifs based on various forms of traditional toys.

Guntur (2015), "Kreasi Motif Batik Khas Mojokerto Berbasis Relief Candi sebagai Kearifan Lokal dengan Teknologi Saring-Malam Guna Meningkatkan Produksi dan Ekonomi Masyarakat" ("The Creation of Mojokerto's Distinctive Batik Motif Based on Temple Relief as Local Wisdom with Night-Screen Technology to Increase Community Production and Economy"). Research of the Ministry of Research, Technology and Higher Education, This study seeks to explore the values of local wisdom reflected in the relief of the temple as the basis for the development and creation of typical Mojokerto batik motifs. In addition to the different research locations, Guntur creates batik with filter techniques that resemble screen printing, while the proposed research still adheres to classical batik techniques to achieve quality aesthetic qualities.

Maryono (2015), "Situs Purbakala Sangiran Sebagai Sumber Ide Pengembangan Motif Batik Dalam Upaya Peningkatan Perekonomian dan Media Penguatan Kearifan Muatan Lokal di Kabupaten Sragen" ("Sangiran Archaeological Site as a Source of Ideas for Developing Batik Motifs in an Effort to Improve Economy and Media Strengthening Local Content Wisdom in Sragen Regency") Research of the Ministry of Research, Technology and Higher Education. Batik-themed research that has been carried out as an effort to strengthen the values of local wisdom by developing batik motifs with the source of the Sangiran site as a characteristic of Sragen.

Dharsono (2005), "Pohon Hayat: Simbol dan makna pohon hayat yang terlukis pada batik klasik sebagai 
ekspresi kebudayaan Jawa" ("Hayat Tree: Symbols and meanings of life trees painted on classical batik as an expression of Javanese culture") Dissertation, published in 2007, titled Budaya Nusantara (2007) (Nusantara Culture (2007)), Study of mandala concepts and tri-Loka / Buana concepts on motifs tree life on classical batik, Bandung: Rekayasa Sains. The book contains research on the topic "Tree of Life", examining the symbols and their meaning in the context of Javanese culture. The study is focused on obtaining information about symbols and their meanings based on the structure and the process of formation and development. This study can show the existence of life trees which are painted as one of the classic batik motifs as an expression of Javanese culture. The main purpose of this research is focused on searching, finding meaning, and describing in-depth and thoroughly the study of life trees painted as batik motifs.

Muh. Arif Jati (2009), "Optimalisasi kawasan Sukuh dan Cetho Kabupaten Karanganyar dengan Menggali Potensi Seni Tradisi Sebagai Pengembangan Ekonomi Kreatif” ("Optimizing the Sukuh and Cetho Karanganyar Regency by Exploring the Potential of Traditional Arts as Creative Economy Development") in 2009. Research on the tourist area was also carried out by Muh. Arif Jati Purnomo entitled, "Implementasi Model Seni Wisata yang Berbasis Budaya Lokal Sebagai Pemberdayaan Masyarakat Kawasan Merapi Pasca Erupsi" ("The Implementation of a Local Culture-Based Tourism Art Model as a Community Empowerment for Post-Eruption Merapi Areas") in 2012. Muh. Arif Jati Purnomo conducted a study, "Optimalisasi Batik Tradisional Surakarta Implementasinya pada Aksesoris berbasis tradisi sebagai upaya Pengokohan Budaya Lokal dan Pendukung Wisata Daerah Surakarta di Era Global" ("Optimizing the Traditional Batik of Surakarta Its Implementation on traditionbased Accessories as an effort to Strengthen Local Culture and Supporting the Tourism of the Surakarta Region in the Global Era") in 2010. Another batik research conducted by Muh. Arif Jati Purnomo is, "Oey Soe Tjoen, Konsistensi Tradisi dan Kualitas Batik Encim di Pekalongan" ("Oey Soe Tjoen, Tradition Consistency and Quality of Encim Batik in Pekalongan") in 2008.

\section{Discussion}

The Garudeya sculpture is a symbol of Garuda as a liberator figure who is part of the search for Tirta Amerta (water of life) story contained in The Adiparwa book, the first book of The Mahabharata. On the tail of the Garuda there is an inscription (inlay writing) that reads lawase rajeg wesi duk pinerp kapeteg dene wong medang ki hempu rama karubuh alabuh geni harbut bumi kacaritane babajang mara mari setra hanang tang bango (iron stabs in a pinerp cap and a man goes out of his head as a fireplace ravages the earth's crust when it comes to attacking a crane) according to the reading of Darmosoetopo (1984). At the point of this inscription is a suryasengkala representing the year of 1363 Saka (1441 AD).

Then as part of the story of the search for amerta in this section, there are also three tortoise statues depicting the earth and the incarnation of the Lord Vishnu. The shape of the tortoise resembles a table and is probably designed as a place to serve. A pyramid with a clipped peak symbolizes Mount Mandaragiri whose peak was taken to stir up the ocean in search of tirta amerta.

\section{Revitalizing Garap}

\section{Design 1:}

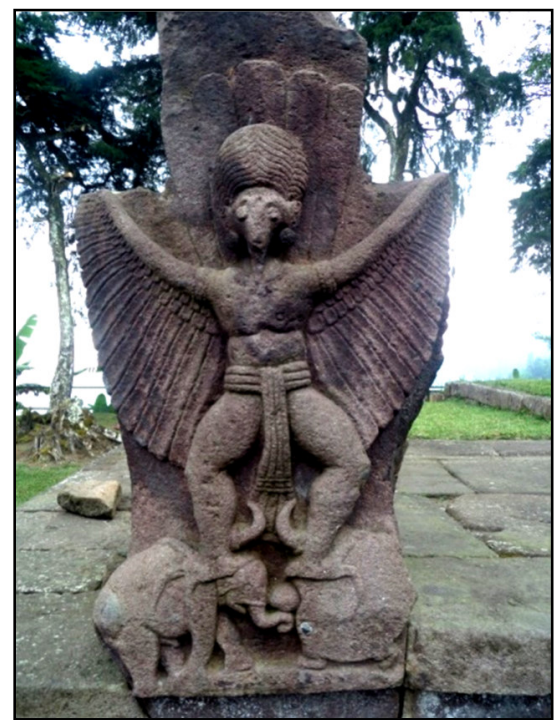

Image: Garudeya Sculpture of Sukuh Temple in Karanganyar (photo: Arthea 2017) 
Batik prototype 1: is a revitalization of the garudeya sculpture found in the Sukuh Temple (see prototype 1).

\section{Revitalizing Garap}

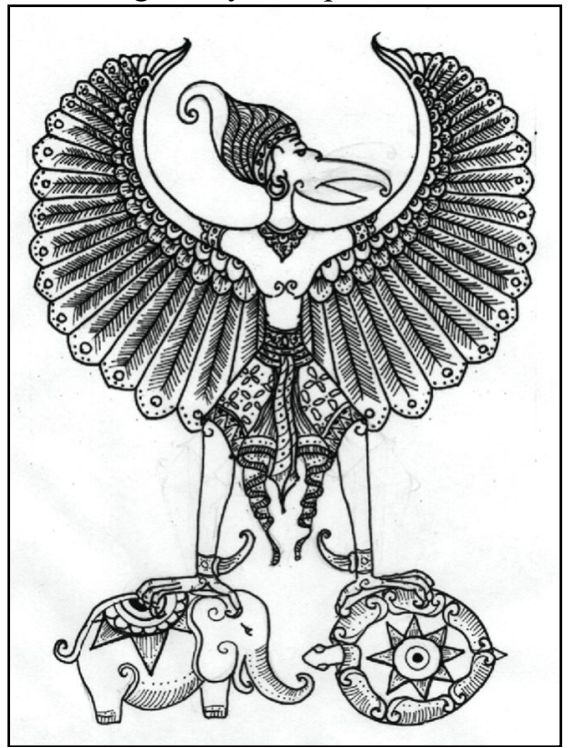

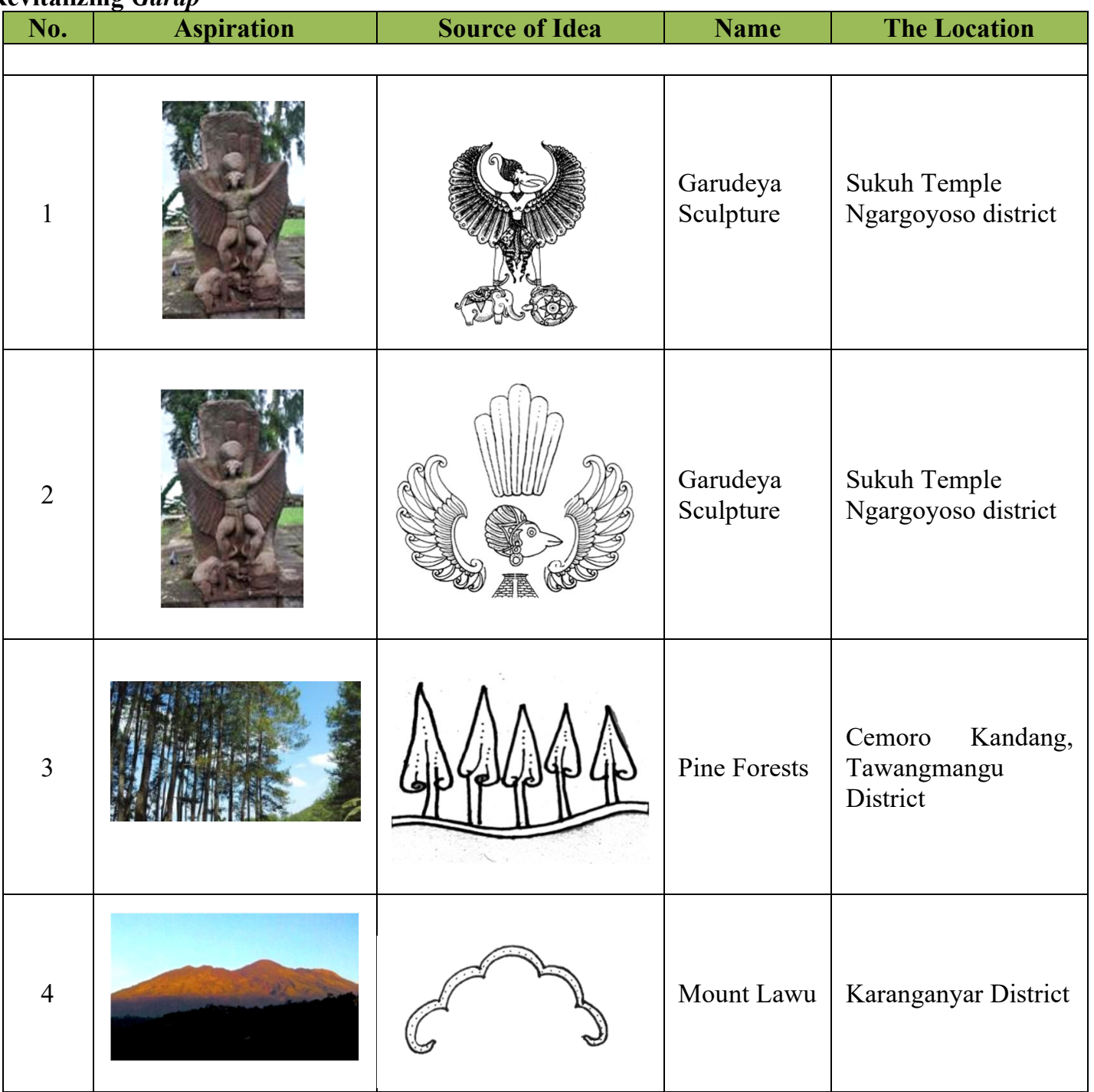




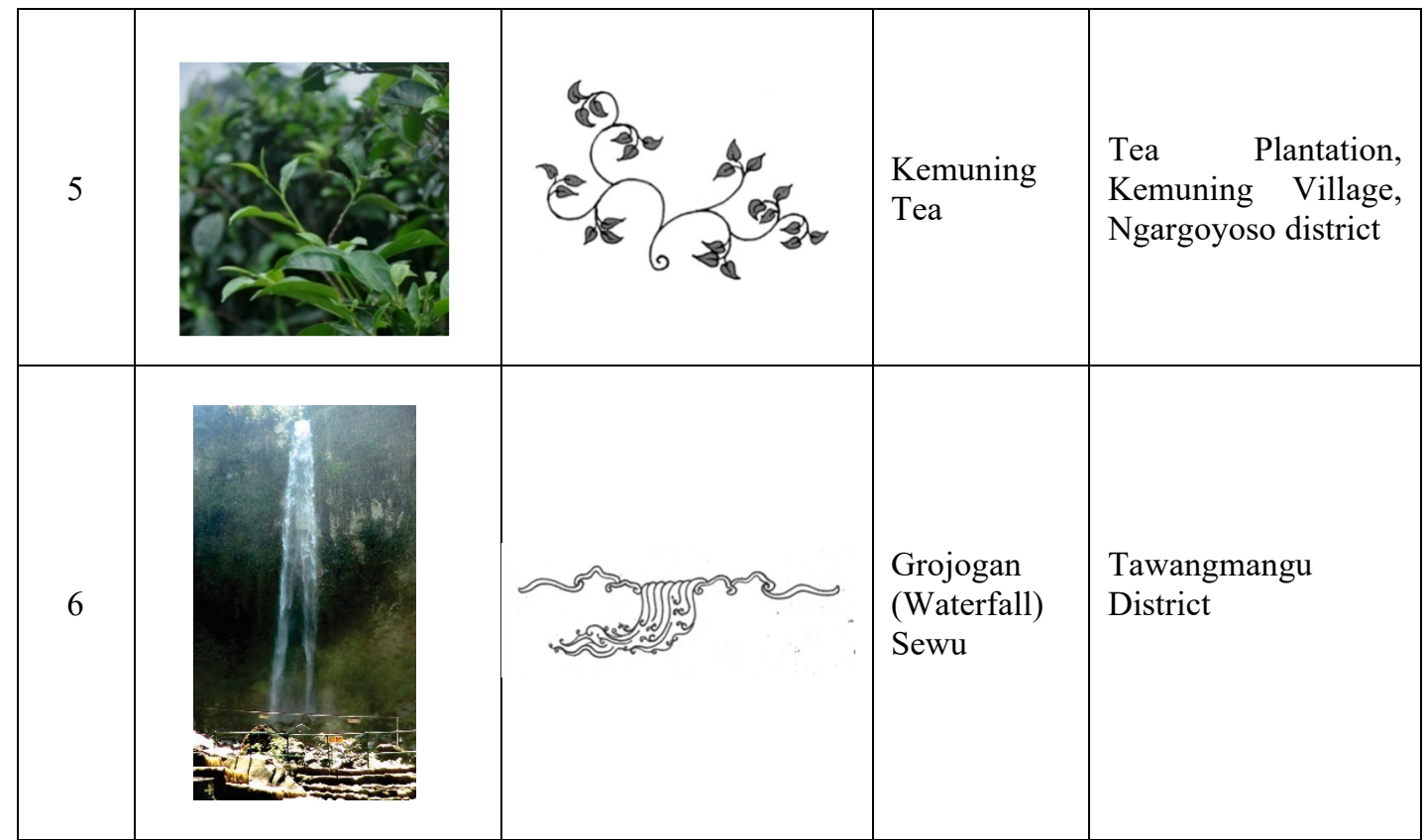
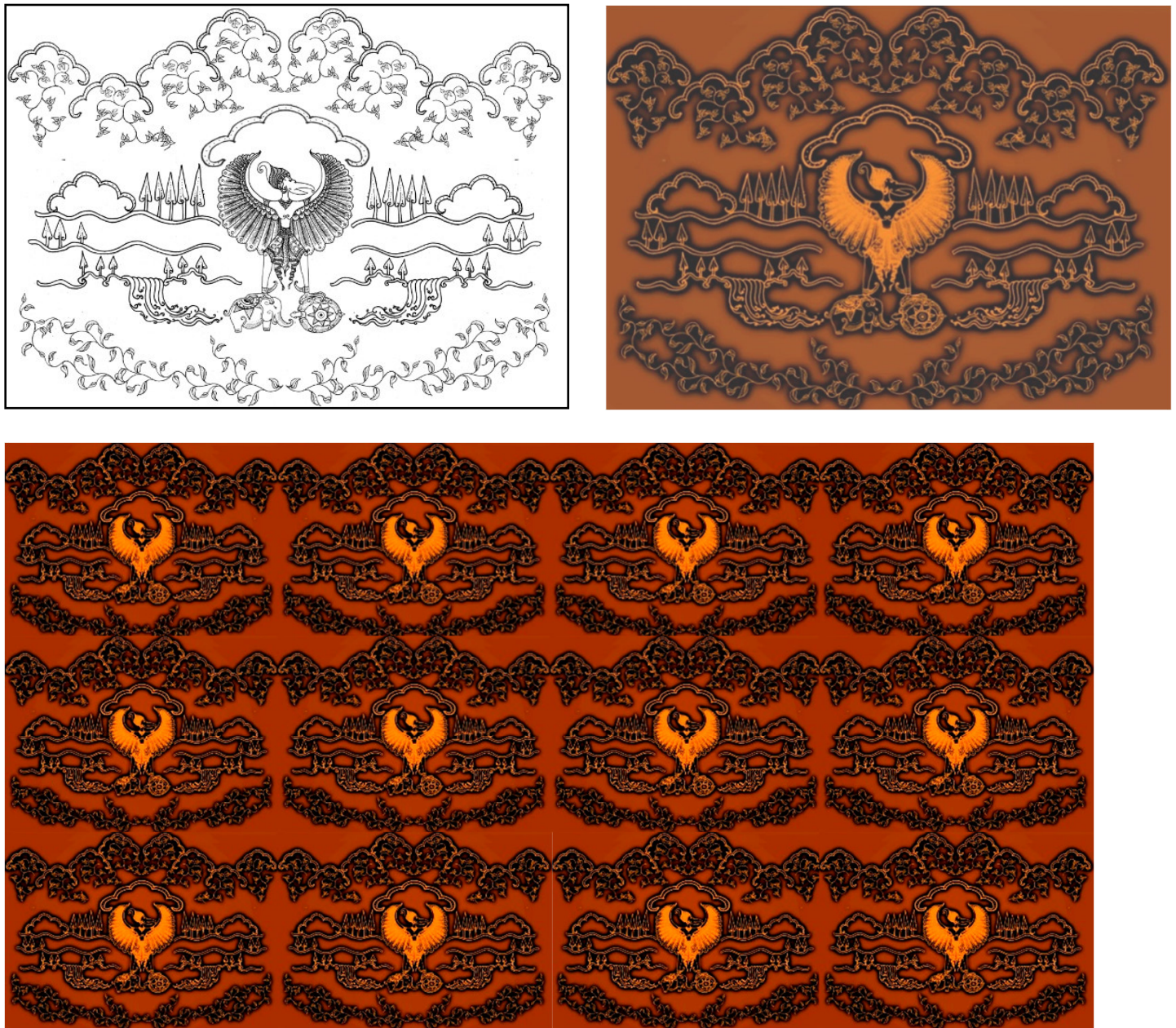

Image:

Batik Garudeya 1 (Arthea, 2017)

This batik is arranged in a revitalized manner with sources of ideas derived from natural wealth and tourist charm in the district. Karanganyar, among others, as the center of interest is the symbol of Garudeya clutching elephants and tortoises carved into the reliefs of the Temple contained in Sukuh Temple, beyond the unity of the two reliefs combined as a supporting motif, among others, 
the motif of the Tea Kemuning leaves, the charm of Mount Lawu which cannot be off with the

\section{Reinterpretation Garap} pine forests and Grojogan Sewu waterfalls.
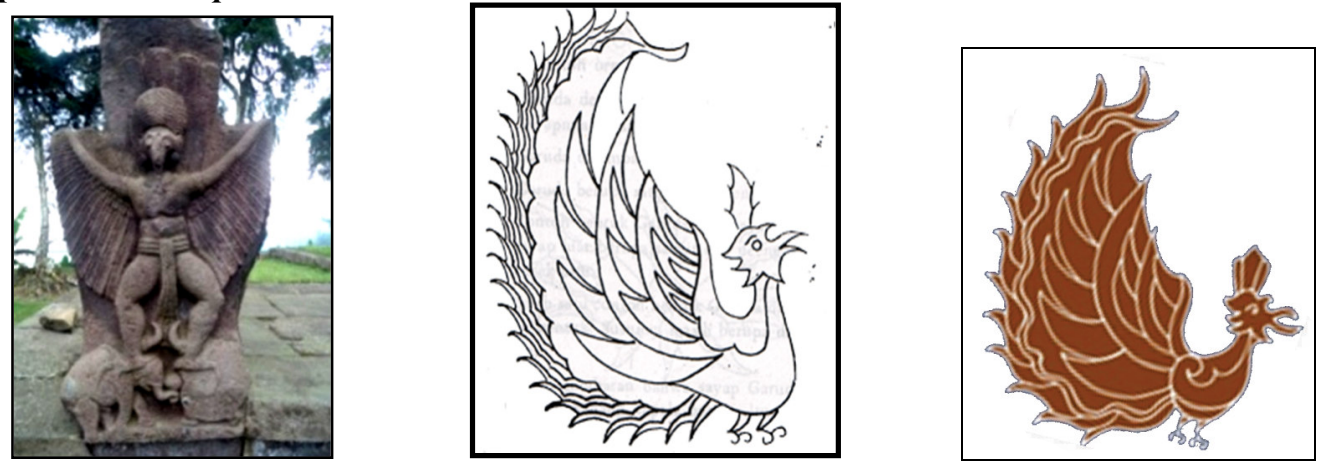

The Garuda Motive Orientation is depicted as a closed wing, with each wing strung together with a closed wing motif, as if the bird that was on its side was seen to be seen sideways. The specifications of this motif of the body and head appear, such as the depiction of birds from the side view. Sometimes in certain areas, the head of a bird is replaced by the head of a dragon or giant head (Sewan Susanto 1980: 265-266).

\section{Reinterpretation 1}
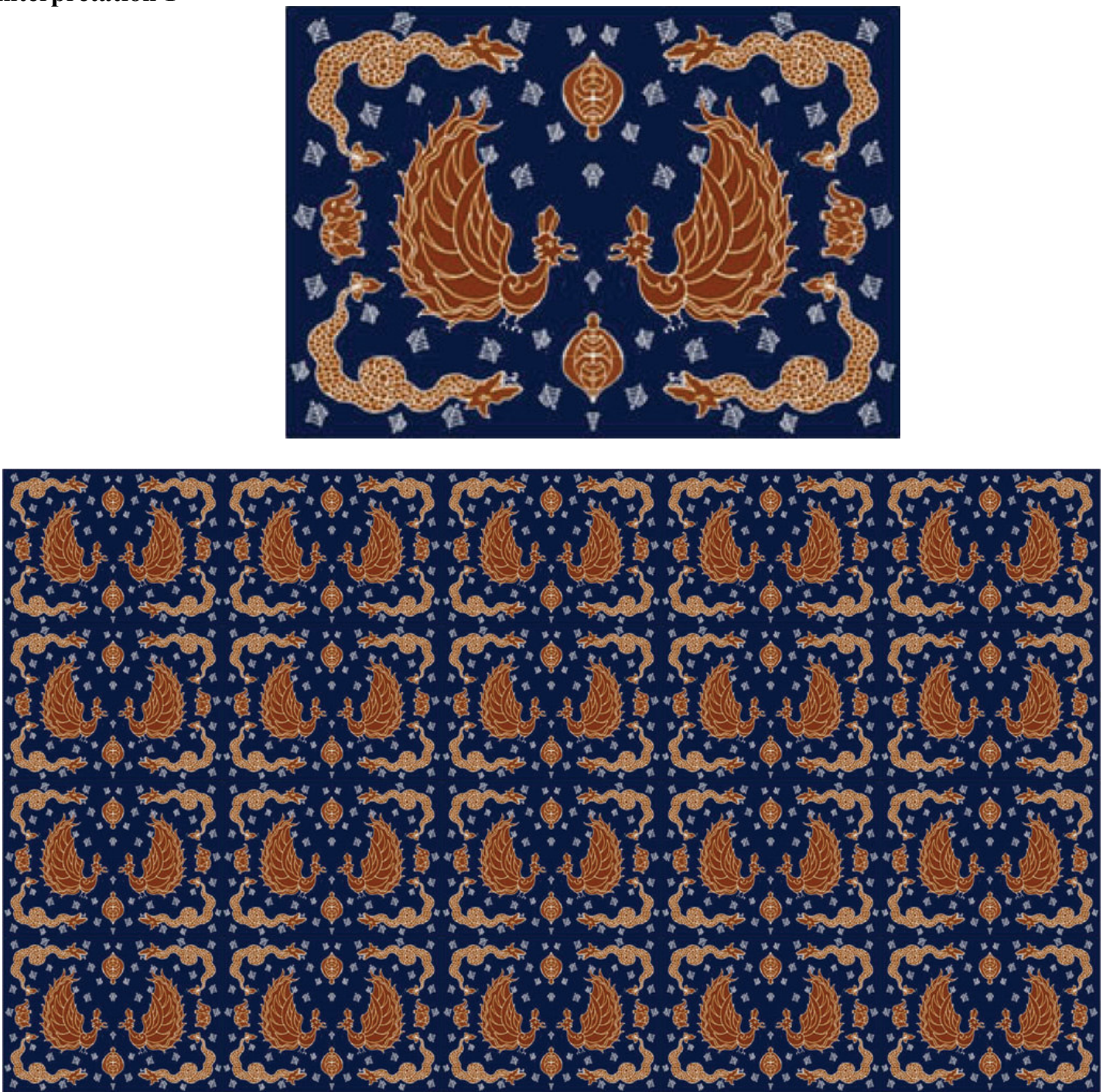

Image:

Garudeya Batik 1 (Swesti 2017)

This batik was arranged in a reinterpretation with sources of ideas derived from natural wealth and tourist charm in the district. Karanganyar, among others, as the center of interest is the symbol of Garudeya engraved in the relief of the Temple contained in the Sukuh Temple, the Garudeya motif 
as the main motif combined with the dragon motif and the tortoise motif as supporting motifs, are separately structured and developed but still represent the symbolic meaning Garudeya Sukuh Temple, beyond the main motive combined with natural tourist charm motifs as supporting motifs such as the Kemuning Tea leaf motif, the charm of Mount Lawu.

Reinterpretation 2
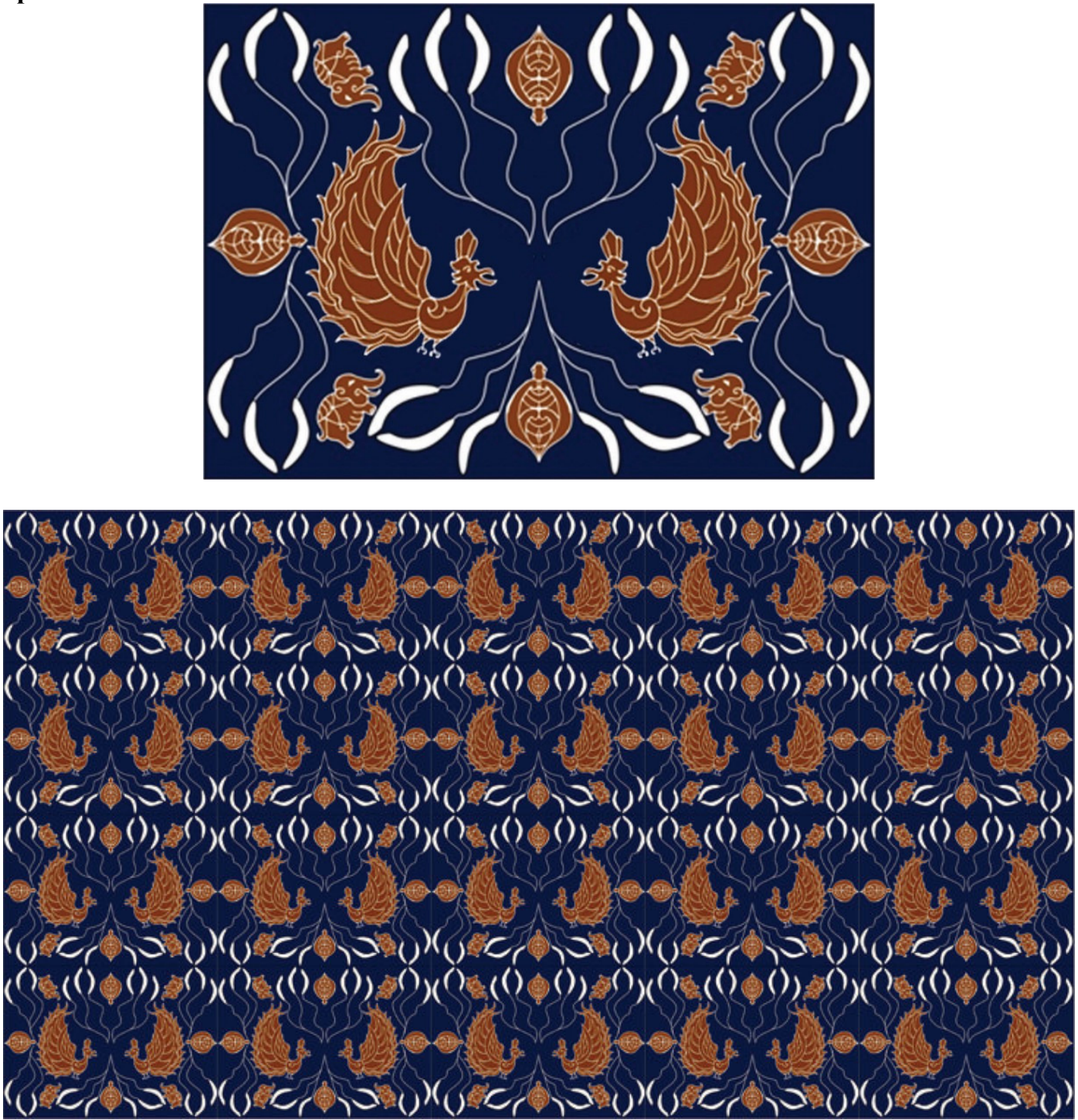

Image:

Garudeya 2 (swesti, 2017)

This batik is arranged in a reinterpretation with sources of ideas derived from natural wealth and tourist charm in the district. Karanganyar, among others, as the center of interest is the symbol of Garudeya engraved in the relief of the Temple contained in Sukuh Temple, Garudeya motif as the main motif combined with the tortoise motif as a supporting motif, separately structured and developed but still representing the meaning of the Garudeya symbol Sukuh Temple Apart from the main motive, the natural tourism charm motifs combined as supporting motifs include the Kemuning Tea leaf motif. 


\section{Reinterpretation 3}
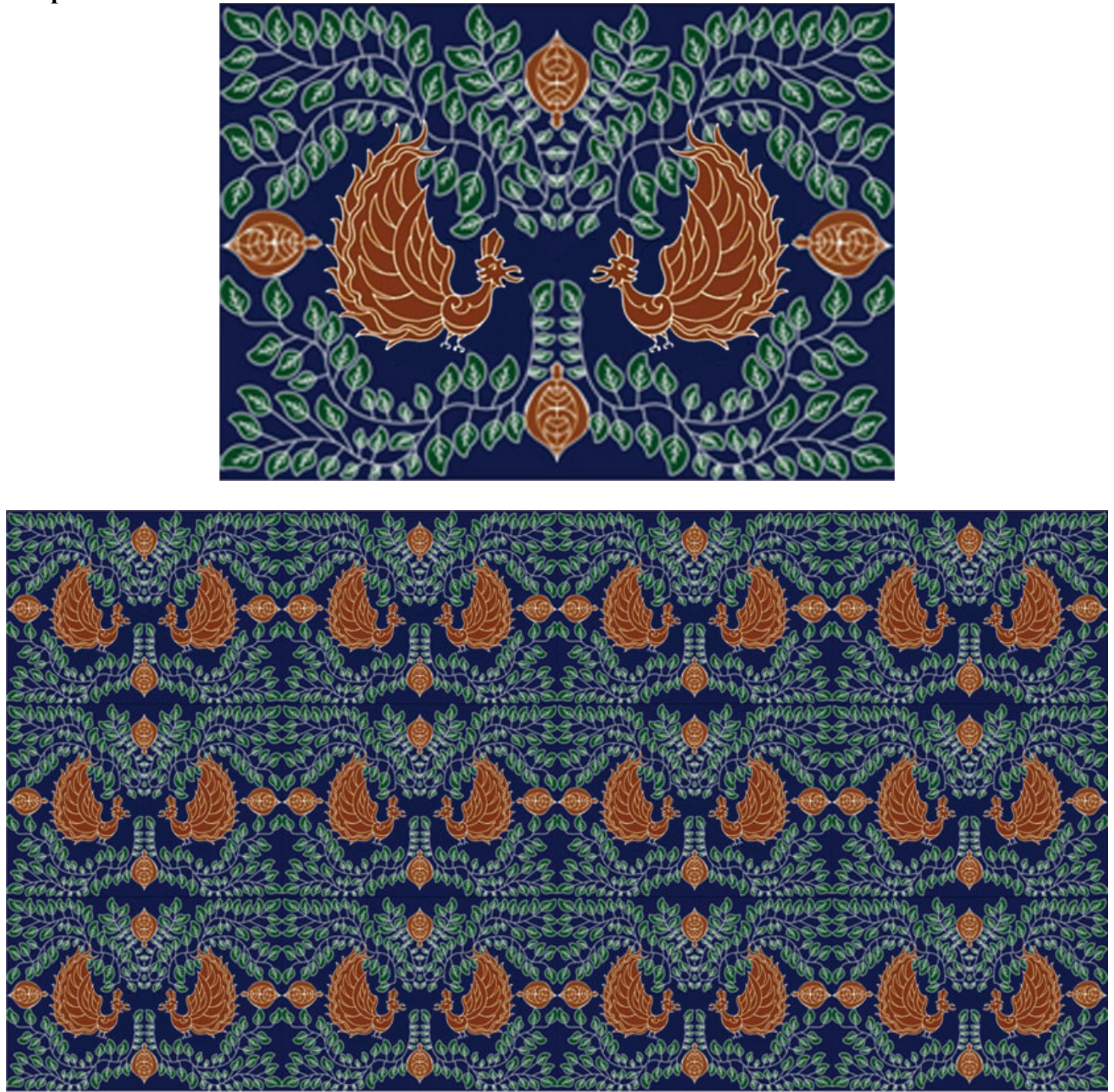

Image:

Garudeya 3 (swesti, 2017)

This batik is arranged in a reinterpretation with sources of ideas derived from natural wealth and tourist charm in the district. Karanganyar, among others, as the center of interest is the Garudeya symbol engraved in the reliefs of the Temple contained in the Sukuh Temple, the Garudeya motif as the main motif combined with the tortoise motif as a supporting motif, separately structured and developed but still representing the meaning of the Garudeya symbol Sukuh Temple Apart from the main motives, the combined motifs of the charm of nature tourism as supporting motives include the motifs of the Tea Kemuning leaves, the charm of Mount Lawu.

\section{Conclusion}

Batik creative design as an innovative design with the concept of batik patterns and layout; First: This batik is prepared in a revitalized manner with sources of ideas derived from natural wealth and tourist charm in the district. Karanganyar, among others, as the center of interest is the symbol of Garudeya clutching elephants and turtles carved into the reliefs of the Temple contained in Sukuh Temple, beyond the unity of the two reliefs combined as a supporting motif, among others, the motif of the Tea Kemuning leaves, the charm of Mount Lawu which cannot be off with the pine forests and Grojogan Sewu waterfalls.

Second: This batik is arranged in a reinterpretation with sources of ideas derived from natural wealth and tourist charm in the district. Karanganyar, among others, as the center of interest is the Garudeya symbol engraved in the reliefs of the Temple contained in the Sukuh Temple, the Garudeya motif as the main motif combined with the tortoise motif as a supporting motif, separately structured and developed but still representing the meaning of the Garudeya symbol Sukuh Temple Apart from the main motives, the natural tourism charm motifs combined with supporting motifs include the Kemuning Tea leaf motif. 


\section{References}

Cook, R. (1995). The Tree of Live, Image for the Cosmos. Slovenia: Mladinska Knjiga.

Cooper, J.C. (1979). An Illustrated Encyclopaedia of Traditional Symbols. London: Themes and Hudson Ltd.

Dharsono (Sony Kartika). (2007 ). Budaya Nusantara, kajian konsep mandala dan konsep tri-loka terhadap pohon hayat pada batik klasik, Bandung: Rekayasa Sains

(2013). Wacana Seni Nusantara. Jakarta: Trisakti Press

(2016). Kreasi Artistik, perjumpaan tradisi modern dalam paradigma kekaryaan seni. Karanganyar: Citra Sain LPKBM.

Gustami, SP. (1989). "Konsep Gunungan dalam Seni BudayaJawa Manifestasinya di Bidang Seni Ornamen”: Sebuah Studi Pendahuluan, Penelitian Yogyakarta: Balai Penelitian Institut Seni Indonesia.

Hadiwijono, H. (tt). Kebatinan Jawa dalam Abad 19, Jakarta,BPK

Hamzuri. (2000). Warisan Tradisional Itu Indah dan Unik, Jakarta: DPK, DirJen Keb, Dir. Permuseuman.

Holt, C. (1967). Art in Indonesia: Continuities and Change. Ithaca New York. Cornell University Press.

Hoop, A.N.J. Th.a Th. Van Der. (1949). Indonesische Siermotieven, Uitgegeven Door Hiet, Koninklijk Bataviaasch Genootschap Van Kunsten en Wetenschappen.

Huberman, Michael A. \& Matthew B. Miles. (1994). "Data Management and Analysis Methods," dalam Norman K. Denzin \& Yvonna S. Lincoln, ed., Handbook of Qualitative Research. London: Sage Publications, Inc. Humardani,SD. (1981). Masalah-Masalah Dasar Pengembangan Seni Tradisi. Surakarta: ASKI. 